\title{
Inter-retrotransposon-amplified polymorphism markers for germplasm characterization in Manihot esculenta (Euphorbiaceae)
}

\author{
A.M. Oliveira-Silva ${ }^{1}$, G.F. Silva ${ }^{2}$, M.C. Dias ${ }^{2}$, C.R. Clement ${ }^{3}$ and \\ N.R. Sousa ${ }^{2}$ \\ ${ }^{1}$ Programa de Pós-Graduação em Biotecnologia, \\ Universidade Federal do Amazonas, Manaus, AM, Brasil \\ ${ }^{2}$ Laboratório de Biologia Molecular, Embrapa Amazônia Ocidental, \\ Manaus, AM, Brasil \\ ${ }^{3}$ Instituto Nacional de Pesquisas da Amazônia, Manaus, AM, Brasil \\ Corresponding author: N.R. Sousa \\ E-mail: nelcimar.sousa@embrapa.br
}

Genet. Mol. Res. 13 (2): 3800-3804 (2014)

Received February 13, 2013

Accepted July 1, 2013

Published May 16, 2014

DOI http://dx.doi.org/10.4238/2014.May.16.3

\begin{abstract}
Manioc, Manihot esculenta, is economically important in many tropical and subtropical countries. The genetic variability of the species has not been fully explored, and new information may help expand its use. Molecular markers based on retrotransposons have good potential for analysis of genetic diversity given their abundance in the genome. Eight long terminal repeat retrotransposons were selected for the development of interretrotransposon-amplified polymorphism markers. To test these primers, we analyzed 32 varieties from Anori, 30 from Manicoré and 10 Mandiocabas from the Manioc Germplasm Bank at Embrapa
\end{abstract}


Western Amazonia. The six informative primer pairs yielded 2060 polymorphic bands, averaging 92\% polymorphism (51.7-98.4) and 0.37 heterozygosity $(0.17$ to 0.40$)$, with a Shannon information index of 0.54 (0.26-0.59). These markers can be used to explore the genetic diversity of manioc.

Key words: Inter-retrotransposon-amplified polymorphism; Polymorphism; Genetic diversity; Varietal discrimination

\section{INTRODUCTION}

Manioc (Manihot esculenta Crantz) is a perennial shrub in the Euphorbiaceae that is a major carbohydrate crop in tropical and subtropical countries, where it is mainly used for the production of flour, pure starch, fresh consumption, and assorted industrial uses. Although propagated vegetatively, manioc has great genetic variability because sexual reproduction continues, often resulting in polyclonal varieties (Silva et al., 2001). These local varieties, grown mostly by small-holder farmers, represent the genetic resources conserved and used in breeding programs.

Molecular markers are used to increase the discriminatory power of genetic variability analyses among manioc varieties. Although there are numerous published markers, there is still a need for new and more variable genetic markers, given the polyclonal nature of manioc varieties. Markers based on retrotransposons (IRAP - inter-retrotransposon-amplified polymorphism) generate great quantities of information, making them good tools for detecting genomic changes associated with their activity, because they create large and stable insertions in the genome; they are highly reproducible, show abundant polymorphism, and are easily viewed in a single gel (Kalendar et al., 2011). Retrotransposon polymorphisms are detected using marker systems that rely on PCR amplification between long terminal repeat (LTR) ends and some components of flanking genomic DNA. The IRAP products are generated with one or two primers matching either the $5^{\prime}$ - or 3 '-end of the LTR using outward-facing primers (Kalendar and Schulman, 2006).

Several families of transposable elements have been reported in manioc (Gbadegesin et al., 2008). This study describes the development of eight sets of IRAP primers based on retrotransposons to discriminate between manioc clones and varieties.

\section{MATERIAL AND METHODS}

Sequences of LTR retrotransposons were located in Phytozome (http://www. phytozome.net/). LTRs were confirmed with the LTR_Finder software (http://tlife.fudan. edu.cn/ltr_finder/) and cross-checked in GenBank using BLAST (http://www.ncbi.nlm.nih. gov/BLAST/). Eight LTR retrotransposons were selected and the outward-facing primers of the LTRs were designed using Primer3 (Rozen and Skaletsky, 2000) for amplification of the members of a retrotransposon family in head-to-head, head-to-tail and tail-to-tail orientation. Seventy-two manioc plants (32 from Anori, Amazonas, 30 from Manicoré, Amazonas, and 10 "mandiocabas", a very sweet variety) maintained in the Manioc Germplasm Bank at Embrapa Western Amazônia, Manaus, Amazonas, were analyzed to test the information 
content of these IRAP markers.

Total DNA was extracted with 2\% CTAB in the Molecular Biology Laboratory at Embrapa. The $20-\mu \mathrm{L}$ reaction mixture consisted of $0.2 \mathrm{mM}$ dNTPs, $0.5 \mu \mathrm{M}$ forward and reverse primers, $2 \mathrm{mM} \mathrm{MgCl}$, $1 \mathrm{X}$ Taq buffer, $1.5 \mathrm{U}$ Taq GoTaq ${ }^{\circledR}$ DNA polymerase (Promega, USA) and 50 ng template DNA. PCR was performed using the following program: 2 min at $92^{\circ} \mathrm{C} ; 40$ cycles of $15 \mathrm{~s}$ at $92^{\circ} \mathrm{C}, 1 \mathrm{~min}$ at $40-60^{\circ} \mathrm{C}$ (Table 1 ), 2 min at $72^{\circ} \mathrm{C}$; and final extension at $72^{\circ} \mathrm{C}$ for $10 \mathrm{~min}$. Amplifications were carried out in a Veriti Thermal Cycler (Applied Biosystems, USA). PCR products were resolved by electrophoresis on $1.5 \%$ agarose gels in 0.5X TBE buffer stained with ethidium bromide and photographed in a transilluminator (Loccus Biotecnologia, Brazil). Polymorphism was detected by the presence (1) or absence $(0)$ of the PCR product. The percentage of polymorphic loci, expected heterozygosity (Nei's genetic diversity) and Shannon information index were calculated with PopGene 1.31 (Yeh et al., 1999), for each population and overall.

\section{RESULTS AND DISCUSSION}

Two primer pairs (ME_1 and ME_3) produced only six bands and were excluded from further analysis. The others generated 20-60 polymorphic bands with sizes between 100 and $12,000 \mathrm{bp}$ (Tables 1 and 2). With these primers, the two populations and mandiocaba samples showed a mean polymorphism of $92 \%$ (range $=51.7$ to $98.4 \%$ ), 0.37 expected heterozygosity (0.17 to 0.40$)$ and a Shannon information index of 0.54 (0.26 to 0.59) (Table 2). Guo et al. (2006) found $86 \%$ polymorphism with IRAP and REMAP primers in persimmon (Diospyros kaki Thunb.), very similar to the results found here.

In manioc, $69 \%$ polymorphism was previously found with AFLP markers and $56 \%$ with RAPD markers in estimating the genetic variability of 54 varieties (Mühlen et al., 2000), demonstrating that these IRAP markers are more informative than other dominant markers.

Table 1. Characteristics of IRAP primers for Manihot esculenta.

\begin{tabular}{|c|c|c|c|c|c|}
\hline $\begin{array}{l}\text { Primer } \\
\text { name }\end{array}$ & Sequence $\left(5^{\prime}-3^{\prime}\right)$ & $\begin{array}{l}\text { Length } \\
\text { (nt) }\end{array}$ & $\mathrm{Ta}\left({ }^{\circ} \mathrm{C}\right)$ & Amplicon size (bp) & $\begin{array}{l}\text { Scaffold location } \\
\text { Phytozome v.9.0 }\end{array}$ \\
\hline$\overline{\text { ME_1 }}$ & $\begin{array}{l}\text { CTGCATTTGAAGTTTGGTCCA }^{\mathrm{a}} \\
\text { TTTCCAGCTTATTGCTTGGG }^{\mathrm{b}}\end{array}$ & $\begin{array}{l}21 \\
20\end{array}$ & 60 & $150-1500$ & $00579: 8924 . .18923$ \\
\hline ME_2 & $\begin{array}{l}\text { GGTGATGATGTGTCCCTTCC }^{a} \\
\text { CTAGTGTATACCCAATATGCCC }^{b}\end{array}$ & $\begin{array}{l}20 \\
22\end{array}$ & 49 & $200-4000$ & 06700:127431..132763 \\
\hline ME_3 & $\begin{array}{l}\text { TCCATCAAATGGGTCTCTCA }^{\mathrm{a}} \\
\text { ACCCAGCATTTCAAGTCTCG }^{\mathrm{b}}\end{array}$ & $\begin{array}{l}20 \\
20\end{array}$ & 50 & $200-2000$ & 03122:396999..406998 \\
\hline ME_4 & $\begin{array}{l}\text { TGGAGCTTGAGGGTGTAAGG }{ }^{\mathrm{a}} \\
\text { TTCGATTGCTTCTCTCCTGC }^{\mathrm{b}}\end{array}$ & $\begin{array}{l}20 \\
20\end{array}$ & 48 & $100-5000$ & 00077:42599..52000 \\
\hline ME_5 & $\begin{array}{l}\text { GCAAGGAGGGGGAATAAAAG }^{a} \\
\text { GCTTCTTTCTTACCGGGCTT }^{b}\end{array}$ & $\begin{array}{l}20 \\
20\end{array}$ & 40 & $100-4000$ & 03413:6000..16000 \\
\hline ME_6 & $\begin{array}{l}\text { TTTTTCATTTTCTTACTTTCTGTGTAA }{ }^{\mathrm{a}} \\
\text { CCTATGATTATGCTATCAATTATCAC }^{\mathrm{a}}\end{array}$ & $\begin{array}{l}27 \\
26\end{array}$ & 42 & $150-1800$ & 09428:1..12686 \\
\hline ME_7 & $\begin{array}{l}\text { TTTCTTGATTCCCAAGGGTG } \\
\text { CCTCTCCATATTCTCTTCTCC }^{\mathrm{b}}\end{array}$ & $\begin{array}{l}20 \\
21\end{array}$ & 48 & $200-3000$ & 01259:102333..122332 \\
\hline ME_8 & $\begin{array}{l}\text { GGTGAATTTCGGTTATTGAA }^{\mathrm{a}} \\
\text { CCAGAGAATGATGTTGAAGG }^{\mathrm{b}}\end{array}$ & $\begin{array}{l}20 \\
20\end{array}$ & 56 & $100-12000$ & 03481:28000..36000 \\
\hline
\end{tabular}

aPrimer designed from 5'-LTR end; ${ }^{\text {a }}$ primer designed from 3'-LTR end; Ta = annealing temperature; nt = nucleotide. 


\begin{tabular}{|c|c|c|c|c|c|c|}
\hline Primer & Samples & No. of plants & No. polymorphic bands & $\mathrm{h} \pm \mathrm{SD}$ & $\mathrm{I} \pm \mathrm{SD}$ & $\%$ \\
\hline \multirow[t]{4}{*}{ ME_2 } & Anori & 32 & 25 & $0.38 \pm 0.17$ & $0.55 \pm 0.23$ & 89.3 \\
\hline & Manicoré & 30 & 24 & $0.32 \pm 0.18$ & $0.47 \pm 0.24$ & 85.7 \\
\hline & Mandiocaba & 10 & 19 & $0.26 \pm 0.20$ & $0.38 \pm 0.28$ & 67.8 \\
\hline & Total & 72 & 25 & $0.36 \pm 0.16$ & $0.52 \pm 0.22$ & 89.2 \\
\hline \multirow[t]{4}{*}{ ME_4 } & Anori & 32 & 26 & $0.30 \pm 0.18$ & $0.45 \pm 0.24$ & 89.6 \\
\hline & Manicoré & 30 & 24 & $0.30 \pm 0.19$ & $0.44 \pm 0.26$ & 82.7 \\
\hline & Mandiocaba & 10 & 15 & $0.17 \pm 0.19$ & $0.26 \pm 0.27$ & 51.7 \\
\hline & Total & 72 & 26 & $0.32 \pm 0.18$ & $0.47 \pm 0.26$ & 89.6 \\
\hline \multirow[t]{4}{*}{ ME_5 } & Anori & 32 & 33 & $0.34 \pm 0.16$ & $0.50 \pm 0.22$ & 89.2 \\
\hline & Manicoré & 30 & 32 & $0.31 \pm 0.17$ & $0.46 \pm 0.24$ & 86.5 \\
\hline & Mandiocaba & 10 & 24 & $0.25 \pm 0.21$ & $0.37 \pm 0.30$ & 64.8 \\
\hline & Total & 72 & 33 & $0.36 \pm 0.15$ & $0.52 \pm 0.21$ & 89.2 \\
\hline \multirow[t]{4}{*}{ ME_6 } & Anori & 32 & 21 & $0.36 \pm 0.17$ & $0.52 \pm 0.23$ & 87.5 \\
\hline & Manicoré & 30 & 22 & $0.34 \pm 0.18$ & $0.50 \pm 0.24$ & 91.6 \\
\hline & Mandiocaba & 10 & 18 & $0.27 \pm 0.19$ & $0.41 \pm 0.27$ & 75.0 \\
\hline & Total & 72 & 22 & $0.39 \pm 0.17$ & $0.55 \pm 0.22$ & 91.6 \\
\hline \multirow[t]{4}{*}{ ME_7 } & Anori & 32 & 19 & $0.30 \pm 0.17$ & $0.45 \pm 0.24$ & 82.6 \\
\hline & Manicoré & 30 & 19 & $0.31 \pm 0.19$ & $0.45 \pm 0.26$ & 82.6 \\
\hline & Mandiocaba & 10 & 13 & $0.23 \pm 0.22$ & $0.33 \pm 0.31$ & 56.5 \\
\hline & Total & 72 & 20 & $0.32 \pm 0.18$ & $0.48 \pm 0.24$ & 90.0 \\
\hline \multirow[t]{4}{*}{ ME_8 } & Anori & 32 & 59 & $0.39 \pm 0.12$ & $0.57 \pm 0.15$ & 96.7 \\
\hline & Manicoré & 30 & 60 & $0.40 \pm 0.11$ & $0.59 \pm 0.14$ & 98.4 \\
\hline & Mandiocaba & 10 & 52 & $0.31 \pm 0.17$ & $0.46 \pm 0.23$ & 85.2 \\
\hline & Total & 72 & 60 & $0.42 \pm 0.09$ & $0.61 \pm 0.11$ & 98.4 \\
\hline Mean & & & & $0.37 \pm 0.15$ & $0.54 \pm 0.20$ & 92.0 \\
\hline
\end{tabular}

$\mathrm{h}=$ Nei's genetic diversity \pm standard deviation $(\mathrm{SD}) ; \mathrm{I}=$ Shannon information index $\pm \mathrm{SD} ; \%=$ percentage of polymorphic loci.

\section{CONCLUSIONS}

This is the first report of IRAP markers to characterize manioc varieties. They proved to be efficient in estimating the percentage of polymorphism and genetic diversity, and will likely permit good variety discrimination.

\section{ACKNOWLEDGMENTS}

Research supported by EMBRAPA (Project \#0106010071406; Manioc Regional Germplasm Bank), the Foundation of the State of Amazonas (FAPEAM; Master's scholarship to A.M. Oliveira-Silva) and the National Research Council (CNPq; Research fellowship to C.R. Clement). We thank Doriane P. Rodrigues, Federal University of Amazonas, for help with the analysis.

\section{REFERENCES}

Gbadegesin MA, Wills MA and Beeching JR (2008). Diversity of LTR-retrotransposons and Enhancer/Suppressor Mutator-like transposons in cassava (Manihot esculenta Crantz). Mol. Genet. Genomics 280: 305-317.

Guo D, Zhang H and Luo Z (2006). Genetic relationships of Diospyros kaki Thunb. and related species revealed by IRAP and REMAP analysis. Plant Sci. 170: 528-533.

Kalendar R and Schulman AH (2006). IRAP and REMAP for retrotransposon-based genotyping and fingerprinting. Nat. Protoc. 1: 2478-2484.

Kalendar R, Flavell AJ, Ellis TH, Sjakste T, et al. (2011). Analysis of plant diversity with retrotransposon-based molecular 
markers. Heredity 106: 520-530.

Mühlen GS, Martins OS and Ando A (2000). Variabilidade genética de etnovariedades de mandioca, avaliada por marcadores de DNA. Sci. Agric. 57: 319-328.

Rozen S and Skaletsky HJ (2000). PRIMER3 on the WWW for General Users and for Biologist Programmers. In: Bioinformatics Methods and Protocols Methods in Molecular Biology (Krawetz S and Misener S, eds.). Humana Press, Totowa, 365-386.

Silva RM, Bandel G, Faraldo MIF and Martins PS (2001). Biologia reprodutiva de etnovariedades de mandioca. Sci. Agric. 58: 101-107.

Yeh FC, Yang R and Boyle T (1999). PopGen v.1.31. Microsoft Windows-Based Freeware for Population Genetic Analysis: Quick User Guide. University of Alberta/Center for International Forestry Research, Alberta. 